\title{
Expectations from administrative reforms: an attempt to implement the Balanced Scorecard in a public sector organization
}

\author{
Kent Nilsson $^{1}$ \\ Division of Industrial Work Environment, Luleå University of Technology, SE-971 87 Luleå, Sweden
}

\begin{abstract}
The aim of the study is to explore what politicians, administrators and operative employees in a public sector organization expect from a new administrative reform (i.e. an attempt to implement the Balanced Scorecard). A case study approach was chosen and 13 actors were interviewed. The findings shows that the expectations on changes are highest among the politicians, moderate among the administrators and lowest among the operative employees. The differences can be explained by the way the reform is anticipated to favour or disfavour the actors, which in turn are influenced by the actors' past experiences. Another finding is that most of the expressed expectations concern expectations of the administrative reform, but some expectations also concern expectations on the reform.
\end{abstract}

Keywords: administrative reforms, expectations, the Balanced Scorecard, New Public Management, management accounting change

\section{Introduction}

In this study, expectations from administrative reforms in the public sector are being explored. The focus is on an attempt to reform management accounting and control in a political council and administrative agency in a Swedish municipality. The reform was carried out during a time when the administrative agency had a large budget deficit and it was therefore reasonable to assume that the expectations were that the reform could solve this problem. However, as we will see, this was not what was expected from the reform.

The reform concerned the implementation of the Balanced Scorecard in the organization. The Balanced Scorecard was originally developed for private sector organizations, but as a result of the global phenomenon of New Public Management (NPM), the model has become popular also in the public sector (Lapsley \& Wright, 2004; Modell, 2004; Storey, 2002). Albeit difficult to define, NPM is a loose collection of ideals, ideas, and practices, primarily derived from the private sector that travels between countries (c.f. Christensen \& Lægreid, 1999; Hood, 1995). NPM contains many "new" techniques that consultants have taken the opportunity to commercialize. As a hegemonic discourse (Salskov-Iversen et al, 2000, p. 184), NPM creates expectations of a more efficient, effective and accountable public sector (Brunsson \& Olsen, 1993; Sahlin-Andersson, 2002). That many administrative reforms have a

\footnotetext{
${ }^{1}$ Corresponding author: Phone: +46 920492 317; Fax: +46 920491 399; E-mail address: kent.nilsson@ltu.se
} 
strong tendency to fail (Brunsson \& Olsen, 1993) does not seem to stop reformers from continuing to initiate and carry out NPM reforms in hope for improvements of the public sector.

Administrative reforms are commonly described as solutions to problems or as means to change unsatisfying situations and arguments based on these conceptions are often used when new reforms are introduced (Brunsson \& Olsen, 1993; Christensen \& Lægreid, 1999, p. 171). However, this rational and instrumental view has been questioned and challenged by a neoinstitutional school of thoughts according to which reforms are also viewed as responses to external pressure (DiMaggio \& Powell, 1983; Meyer \& Rowan, 1977). Public organizations are expected to respond to different and sometimes contradictory demands from the environment (Meyer and Rowan, 1977) and a way to handle this complexity is to reform some aspects of organizations and make this visible to external observers (Forsell, 2002, p. 265). The effects in terms of actual changes will be limited, but the reforms can work well as façades towards the environment. Many reforms are also results of processes of mimetic isomorphism (DiMaggio \& Powel) or fashion (Abrahamson, 1991; 1996) where attractive or desirable elements from role model organizations are imitated. Furthermore, new solutions are often more attractive than present practice (Forsell, 2002, p. 264) and reforms tend reproduce further reforms and becomes, by that, routines rather than actual breaks in organizational life (Brunsson, 1989a). Therefore, from a neo-institutional perspective, reforms are not only attempts to change or to improve; they are also expressions of hopes for more rationalistic, idealistic and "truer” public organizations (Brunsson, 2006a; 2006b p. 42f).

Inspired by the neo-institutional view of reforms, this study seek to gain understanding of which expectations the administrative reform have created in the political council and administrative agency. Expectations have been studied earlier, but as far as it is possible to determine, no prior research has been conducted that explicitly and empirically investigates expectations from neither administrative reforms nor the Balanced Scorecard in public sector organizations. Further, earlier research on introductions of NPM inspired administrative reforms in public sector organization (e.g. Doolin, 2004) and implementations of the Balanced Scorecard in organizations (Kasurinen, 2002) have shown that various constituencies perceive and enact the reforms differently. Therefore, the expectations will be explored from the perspectives of politicians, administrators and employees at the operative level of the organization $^{2}$. Base on the abovementioned, the aim of the study is to explore what politicians, administrators and operative employees in a public sector organization expect from a new administrative reform.

\section{Conceptual background}

\section{Expectations}

Expectations are thoughts, beliefs and anticipations about the future and they arise often under circumstances of uncertainty. Expectations can be conceptualized in many ways; for example as ideals, norms or predictions (Hubbert et al, 1995), and can further be divided into hopes and fears. Hopes concerns expectations on a positive future or outcome, while fears represent the opposite. Human expectations are not always easy to understand; some expectations can be fully realistic, while others are more or less unrealistic. For example, individuals tend to

\footnotetext{
${ }^{2}$ Employees from the operative level of the organization will be denominated as "operative employees" in the rest of the paper.
} 
expect more danger with flying than with driving, even if most of us are aware that it is statistically safer to travel by air than by cars (Sunder, 2002). Expectations, albeit imaginations unrestricted by reality, can also affect future events as self-fulfilling prophesies.

As mentioned in the introduction of the paper, no prior study has been identified that explicitly and empirically investigates expectations from the Balanced Scorecard. However, research in an adjacent field (i.e. information systems) has shown that user expectations are critical to implementation success (Ginzberg, 1981). More specifically, users' preimplementation expectations regarding the usefulness of systems strongly affect their subsequent beliefs about systems and also their use of the systems (Stone, 1995). Users with high expectations tend to be more satisfied and perceive the systems as more useful, and as a consequence, use the systems in lager extent compared with actors with low expectations (Szanja and Scamell, 1993). This implies that high user expectations are desirable but this is not always the case. Staples et al (2002) found that users with unrealistically high preimplementation expectations will experience lower levels of perceived benefits (i.e. postexperiences), compared with users with realistic expectations (i.e. expectations that match post-experiences). This is similar to Lyytinen's (1988) notion of “expectations failures”, an important explanatory factor for implementations failures. Expectation failures occurs when there is a gap between stakeholders' expectations expressed in some ideal or standard and the actual performance of a system.

\section{The Balanced Scorecard}

The concept "Balanced Scorecard" is in this study used as a generic term for formal control models that has a specific set of design characteristics that distinguish them from other management accounting and control models ${ }^{3}$. Unique design characteristic for these models are that financial and non-financial objectives and measures are included into one single model with different perspectives ${ }^{4}$, while traditional accounting-based control models contain only financial measures and/or objectives (Dinesh \& Palmer, 1998; Kaplan \& Norton, 1992; Malmi, 2001). Further, both objectives and measures are necessary design characteristics since models including measures without objectives are better described as information systems than as control models ${ }^{5}$ (Malmi, 2001) and objectives without related measures are more synonymous with leadership (i.e. management by objectives) than with formal control models.

Literature that covers Balanced Scorecard are often characterised by rich and illustrative descriptions of how these models works, how they should be applied when they are put into practice and uncritical stories of successful adoptions in organizations. This is especially true for the literature that is primary directed to practitioners (e.g. Kaplan \& Norton 1996; Olve et $a l, 1999)$. However, regardless of the richness of details in this literature, the models are yet characterized by a certain degree of conceptually ambiguity that opens up for multiple

\footnotetext{
${ }^{3}$ Other well-known models within this category are; 'the Performance Pyramid' (Lynch \& Cross, 1991), 'the Results- and Determinants framework' (Fitztgerald et al, 1991) and 'Kanji’s Business Scorecard' (Kanji \& Moura e Sá, 2001).

${ }^{4}$ A perspective is a construct that contains objectives and measures that have similarities that differentiates them from other objectives and measures. Examples of perspectives are; Financial, Customer, Internal process, and Learning and Growth (Kaplan \& Norton, 1996).

${ }^{5}$ Some might argue that measures alone yet can be used for control purposes, especially in cases where outcomes of measures are used in comparisons with measures that reflect historical outcomes or in comparisons with performances of other organizations (i.e. Benchmarking). However, under these circumstance becomes the reference point objectives - even if they originally were measures.
} 
perceptions and interpretations of how the models can be applied (Ax \& Bjørnenak, 2007, p. 367f). This could lead to deviations between the descriptions and guidelines found in literature for a specific model and how the model is actually applied, which in turn could be a serious validation problem for scholars studying these models. For example, an organization can have formally adopted a Results- and Determinants framework, but the model that is actually being applied is more in accordance with how the Performance Pyramid is described in the literature. Which model is then valid? The consequence of this ambiguity could be that the "wrong" model is being studied, for example when effects from, or expectations from, a specific model are searched for. Therefore, it is more appropriate to define the model by making generic conceptualizations in terms of specific design characteristics that differentiate the model from other models or in terms of how the model is actually being applied in practice. In this paper, the former way to define the model is used.

\section{Research Method}

A case study approach was chosen to study expectations from administrative reforms and it was the study's exploratory nature that led to this choice. Due to the research focus, it was important to find a case that concerned an administrative reform with a NPM technique and the attempt to implement the Balanced Scorecard in the political council and administrative agency was considered suitable. The study was designed as a single embedded case study (Yin, 1994, p. 39) with multiple units of analysis which were the three groups of actors; politicians, administrators and operative employees.

The political council and administrative agency were selected as research site for two reasons. First, the political council and the administrative agency had recently begun to implement the Balanced Scorecard and since the aim of this study was to explore expectations from the new administrative reform, the intention was to find a research site where possible effects from the reform was not yet apparent. Second, it was considered important to find a research site whose actors have the ambition to carry out the new reform. According to a process coordinator from the municipality's central administrative agency, the members of the management team of the administrative agency had taken the mission to implement the model seriously, which was far from what some of the other political councils and administrative agencies in the municipality had done.

The empirical data were collected by conducting in-depth interviews with 13 actors from the municipality. The selection of actors was based on role, function or hierarchical position in the organizations, but also on recommendation from participating actors. The ambition was to involve actors from all hierarchical levels of the organization that was directly or indirectly involved in the implementation of the model and that had sufficient knowledge about the reform. Of the actors, two worked at the municipality's central administrative agency and the others were politicians and employees from the political council and administrative agency that was selected as research site. The two actors from the central administrative agency worked as the municipality's chief financial officer and as process coordinator with the responsibility to develop the model and to secure the implementation. Of the politicians, one served as the chairman of the council and the other one was a part-time politician. They represented two political parties, and the chairman's party that had the political majority in the municipality. Of the five administrators, four had leading positions in the administrative agency. One worked as director for the administrative agency, one as chief financial officer and two worked as managers for the two largest operational departments in the administrative agency. The fifth administrator worked as a part-time process coordinator, responsible for 
supporting the implementation of the model in work sites of the administrative agency. The operative employees were represented by two supervisors that were responsible for one work site each, and the other two were subordinates to the supervisors and worked as practical nurses.

Most of the interviews were carried out in May and June 2004, but some initial interviews were also carried out in May 2003. Approximately 40 hours were spent on interviewing and a typical interview lasted between 2 and 3 hours. However, not all of the empirical data that was collected through the interviews are used in this paper. Some of the findings have been reported earlier (Nilsson, 2005) and some data will be reported later. During the interviews, a semi-structured guide was used that contained a few pre-determined themes (c.f. Denzin \& Lincoln, 2000, p. 781), primarily related to expectations from the new reform. The questions in the interview guide were mainly derived from literature, but some questions were designed also as open questions. All interviews were tape-recorded.

The next step was to transcribe all interviews and then carefully read trough the texts and mark everything that was interpreted to be related to expectations from the reform. This resulted in the identification of some recurring themes that finally was narrowed down to five distinctive themes of expectations from the new reform. After this was completed, a new literature review was carried out in order to conceptualise the five themes. The conceptualized themes were then used to reinterpret and reanalyse each theme one more time. After this was completed, it was possible to draw conclusions from the study.

The abovementioned procedure has elements of both induction and deduction by the way empirical data and theory were used cross-sectional. Some theories were used ex ante to guide the collection of the empirical data and to make initial analysis and interpretations of the data, while some theory were used ex post to reanalyze and reinterpret the empirical data. The study is. The intention of the study is not generate generalizations, but rather increase our understanding of expectations from administrative reforms in the public sector and to start building theory that can be developed further by more research in this field.

\section{Empirical study}

\section{Case setting}

At the time of the study, the political council consisted of 15 regular members and of these, only the council's chairman received full-time remuneration. In short, the political mission of the council's is to ensure that the inhabitants of the municipality receive nursing and social care. From the political mission, the council had formulated a vision and a mission statement that the administrative agency should carry out and fulfill. The administrative agency, which is one of the largest administrative agencies in the municipality, employed at the time of the study 4.900 persons (2.900 full-time employees). The year before the study took part, the administrative agency had revenues of 1.2 billion Swedish crowns and a financial budget deficit of nearly - 60 million Swedish crowns. Sickness absenteeism within the administrative agency was very high during this year with an average of nearly 52 days per employee. The formal organization of the administrative agency was divided into three staffing functions and four operational departments that had authority over nearly 100 work sites. At the top of the administrative agency was the director, who headed the administrative agency along with a management team of leading administrators. 


\section{Earlier management control system and organizational culture}

Historically, the administrative agency has applied a traditional budget system with elements of both rule based control and management by objectives (MBO). The ruled based control was regarded by many administrators and operative employees as obsolete and in some cases also inappropriate. The control focus was mainly aimed at discovering deviations from the predefined rules and this created a culture of "the boss is always right". At the same time, many operative employees perceived that they could do whatever they wanted to do - as long as it was not discovered by "the boss". The way the MBO system was applied was not appreciated either, since all objectives were decided by the administrators without any dialogues with the operative parts of the organization. Taken together, earlier management control in the administrative agency control was perceived as vague, top-down and informal.

Further, the politicians were also dissatisfied with earlier management control, mostly because it was the administrators who designed and evaluated all objectives. The politicians perceived that they had only limited chances to influence the administrative agency and if any complaints were made by citizens, the administrators blamed it on the politicians. The information received from the administrators to use for political decisions was considered as inadequate and "everything was like a black box", according to the chairman of the political council. The politicians perceived that it was the administrators, not the politicians that had the real power over the administrative agency with earlier management control.

In the mid-1990s, an attempt to reform the entire municipality organization was made by implementing a new quality control system. The reform became a failure, mostly because the system was considered too complicated, but also because the system was developed for industrial businesses rather than for municipalities. One operative employee who participate in this study was involved in the reform during this time and describe the attempt as "...a total disaster". The chairman of the political council would not want to describe the reform as a disaster, since it prepared the political council and the administrative agency for the problematic nature of reforming the organization in the future.

\section{The new administrative reform}

In the spring of 2001, the central political council of the municipality took the decision to once again try to reform the entire municipality organization. This time, the reform concerned the implementation of a control model that was labeled; "Balanced Control". This model is developed by the Swedish Association of Local Authorities ${ }^{6}$ in corporation with a Swedish consultancy firm (i.e. Sande Konsult AB). The initiative of the reform came from a few leading administrators from the central municipal administration who had some experiences from applying the model in other public organizations. The aim of the reform was to improve the management control systems in the organization and to establish conditions for better planning and evaluations of operations. It was also considered necessary to find a management control model that could complement the municipality's traditional budget system with a systematic quality system and a system to develop the dialogues with the citizens.

The new control model was introduced in the administrative agency in the late 2001 when two work sites begun to apply the model. The following year, politicians and administrators from

\footnotetext{
${ }^{6}$ Svenska kommunförbundet in Swedish.
} 
leading positions in the administrative agency met for several days to design the political council's first "balanced" objectives and measures. The objectives and measures were derived from the vision and mission statement that was formulated. During this session, it was also decided that every staff function, operation department and work site within the administrative agency should use the five perspectives: Financial, Customer/Client/Citizen, Procedures, Employees, and Development. Further, it was decided that some of the objectives designed for the political council must also be used as objectives in every function, department and work site throughout the administrative agency. One of these objectives was "90 percent satisfied clients", which means that the objective was to get 90 percent of all clients in the administrative agency satisfied with the services provided.

After the political council had designed its objectives and measures, the implementation of the model continued in the administrative agency. One important aspect of the implementation process was that superiors and subordinates on every hierarchical level should work together with the design of objectives and measure. An external consultancy firm was hired to develop a model for the implementation at the work sites and four part-time process coordinators from the administrative agency supported the implementation process. A typical implementation process at a work site used to begin with the design of objectives and measures related to the perspective “Customer/Client/Citizen”. The reason for this was that the administrators wanted to clearly emphasize to the employees that the clients are most important. The design of objectives and measures related to the financial perspective were handled last, primarily because many employees tended to lose their enthusiasm for the new model when the severe financial situation of administrative agency came up. Another issue that usually caused some protests among the operative employees was the requirement that the political council's objective of "90 percent satisfied clients" must be used as an objective in every work site. Instead, many employees thought that the objective should be "100 percent satisfied clients".

According to the chairman of the political council, the cost of implementing the model in the administrative agency was estimated to 5.5 million Swedish Crowns and no additional resources were given from the central administrative agency to carry out the reform. Yet, the politicians and the administrators perceived that the implementation of the model had proceeded better than they had expected. However, the operative employees were not that exited. One of the supervisors claimed that; "We've been doing this for ages without calling it Balanced Control", and expressed worries that the new administrative reform will fail: "I'm afraid this will end up like all the other changes here in the municipality - that it will end up in...nothing". At the time of this study, all administrative functions and operational departments, and more than half of the near 100 work sites of the administrative agency had implemented "Balanced Control”.

\section{Expectations from the new administrative reform}

The new administrative reform has created many expectations among the politicians, the administrators and the operative employees. Five themes of expectations from the administrative reform have been identified. These are presented next and summarized in table 1 at the end of the section. 


\section{Participation}

In organizations, participation or participative management refers to different forms of employee involvement (Bainbridge, 1996, p. 675), which can range from the mere presentation of an opinion where the locus of final authority rest elsewhere, to membership in the group which exercise final authority over an issue (Alutto \& Belasco, 1972). The idea to involve employees in the design of organizational arrangement that affect the employees has its origin in the famous Hawthorne studies which gave rise to the Human Relations movement (Macintosh, 1985, p. 10). The expected benefit from making employees more participative is increased job satisfaction which in turn is supposed to lead to improved productivity (Ives \& Olson, 1984).

The single most expressed expectation from the administrative reform was more participation throughout the organization and this was in turn expected to lead to many positive outcomes. The politicians had high expectation that the new reform will make all politicians participative in the design of objectives for the political council. By this, they anticipated that the politicians will feel that it is "their objectives", and not the administrator's objectives that matters. The chairman of the council also hoped that participation in the design of objectives will unite all politicians in the council, irrespective of political ideology. Some top administrators were expected to participate when the politicians design the political council's objectives, but the administrators' role during this process will be to assist the politicians and provide administrative support - not to design the objectives. The politicians also expected that managers and supervisors from the administrative agency will involve their subordinates when they design objectives for their units.

Some of the administrators expected that they will participate when objectives are designed by the politicians and the degree of participation was expected to be decided by the administrators and not by the politicians; "The management team will be involved [in the design of objectives] and we will decide how active or passive we will be" [Emphasis added]. The administrators also had high expectations that all design processes of objectives on every hierarchical level in the agency will be based on dialogues and participation and that is the objectives that the political council has decided to be compulsory. These objectives are "nonnegotiable", according to the administrators. With more participation, the administrators expected increased motivation and commitment among the operative employees, since the employees were expected to feel that; "...they are involved in the management of operations". In turn, this was expected to increase the performances; "If you have some freedom and good signals from management, it's easier to be self-sustaining and perform better", according to the director of the administrative agency. However, the managers from the two departments asserted that the objectives at the work sites must be well thought out; "...otherwise, the objectives won't be used".

The operative employees had also expectations of more participation from the reform, most since; "it's in print that we should be involved". However, the participation of the operative employees was anticipated to be limited since many objectives were expected to be decided from above. A supervisor expressed her thought about this; "Actually, it's about participation in planning and evaluation, but not in designing objectives", and one of the practical nurses felt that; "We will be involved in decision, even though we're actually aren't involved". Some of the operative employees were also suspicious that the "real" purpose with the new administrative reform was to; "Getting on paper what everyone does so they [the politicians and the administrators] can prove that all personnel aren't needed”. One practical nurse 
asserted; "They [the politicians and the administrators] talk so much about this [the new reform] and it's commendable, but you feel like, what's the catch? Everything can't be that great...Hell, we're as efficient as we can be...we can't be any better".

The idea behind making organizational members more participative is to increase job satisfaction that in the end will result in improved productivity (Ives \& Olson, 1984). However, it is only the administrators that express these expectations of the new reform. On the other hand, the expectations of the administrators appear to be a limited form of participation. The participation and involvement of the operative employees in the design of objectives are expected to be high, while at the same time restricted by the way the administrators have the final decision to approve or reject objectives and by the "nonnegotiable" and compulsory objectives that the politicians have decided. The operative employees have also expectations that the reform will not make them fully participative. They anticipate that they cannot completely influence their "own" objectives and they seem to perceive that the rhetoric of empowerment used with the reform, actually is a veiled way to exercise power in order to cut down the work force. This indicates that the administrators and operative employees expect that the new reform will lead to a form of pseudo empowerment (c.f. Macintosh, 1994, p. 246ff) instead of "real” empowerment. Further, the expectation of the politicians that more participation will make them more independent of the administrators when they design objectives and the administrators' anticipation that they decide their degree of participation during these sessions indicates an ongoing power struggle between politicians and administrators.

\section{Effectiveness}

No single definition of effectiveness has become widely accepted (Cameron, 1981), but effectiveness is in general associated with "doing the right things". In organizations, effectiveness refers to the accomplishment of official goals that has either been defined internally or externally by a community or a society (Coulter, 1979; Grusky, 1963). High effectiveness means that the goals have been reached to a satisfactory level and low effectiveness means the opposite. However, effectiveness cannot easily be pinpointed, counted, or objectively specified since effectiveness is a construct that can not be observed directly (Cameron, 1981) and the goals are by nature value-based judgement about the performance of organizations and the criteria for that judgement are whatever various coalitions judge it to be (Quinn \& Rohrbaugh, 1981).

The politicians had high expectations that the new administrative reform will change focus in the organizations. They perceived that the operative employees were putting to much focus on financial issues and the expectations of the politicians were that the new administrative reform will shift focus instead to the clients. The chairman of the council asserted that "the customer, or the client, is very important to us", and he hoped that the new control model would promote this belief to the operative employees. It was foremost the design characteristics of the control model with specific objectives for the clients that gave rise to this hope: "Financial control alone is not enough. It is almost like shooting with a shotgun. By designing objectives for the clients, they also become important". The politician in opposition had also this expectation of the control model and declared that as politicians, it is important to focus on the clients: "It is not particularly smart being politicians and saying that we're going to be less nice to the clients. That usually doesn't go well. As long as we have free elections in this country, the objectives [for the clients] will be set high". 
The administrators also perceived that the operative employees had put to much focus on financial issues and the administrators had high expectations that the operative employees will treat the clients better as a result from the reform. This was expected to be realized by designing and evaluating objectives related to the clients, which in turn were expected to spread the message "we are here for the clients" throughout the administrative agency. It was this message that the administrators most of all would like to get out from the reform.

The operative employees expressed no expectations that the new reforms will lead to any changes concerning priorities or how they treat the clients. According to them, the clients have always been prioritized and will always be, regardless of control model or administrative reform. One of the supervisors asserted that; "I can't see anything being more or less important compared with before", and one of the practical nurses said; "To make the clients satisfied has always been the objective here". According to the operative employees, it was the financial situation for the administrative agency together with the politicians and administrators decisions and actions that had prevented them to satisfy the clients as much as they had wished to do. The reform was not expected to change the situation and one of the practical nurses expressed worries about the future; "We want to do so much and give more to our clients but it will never work-we're fully aware of that, but we really wish it would".

It seems clear that the politicians, the administrators and the operative employees have a shared view of what goal the administrative agency should prioritize and accomplish before anything else - to treat the clients well. However, the politicians and the administrators appear to believe that the operative employees prefer to prioritize financial issues instead of the clients, which seems to be incorrect. The politicians and the administrators hope that the new administrative reform will lead to positive changes in terms of improved effectiveness, but this is not what the operative employee expects from the reform. They would like to prioritize the clients more, but they feel prevented to do this by the poor finances of the administrative agency and the politicians and the administrators. Therefore, the operative employees expect no changes in terms of improved effectiveness from the reform. Instead, they will treat the clients the same as they always have and "doing the right things".

\section{Accountability}

Accountability in its broadest sense refers to the giving and demanding of reasons for conduct (Roberts and Scapens, 1985). Accounts is a central feature of human life (Olson et al, 2001) and a social phenomenon that in its hierarchical form emerges in situations with asymmetrical power relations where an actor feel obligations or is demanded to explain and to justify his or her conduct to someone significant other (i.e. a person, an agency or the general public) (Bovens, 2005, p. 184; Roberts, 1991). Accountability is an elusive concept (Sinclair, 1995) and should not be confused with responsibility. Accountability refers to presentations of action either in the future (ex ante accounts) or action in the past (ex post accounts), while responsibility is action carried out in the present (Olson et al, 2001). Therefore, accounts about actions will always be given before or after the act to which the accounts refers to.

All three groups of actors expected that the new administrative reform will lead to more accountability in the organization, but with some differences. The politicians hoped that the reform will help them to exercise more and better control over the actions taken by the administrators. The politician in opposition anticipated that; "[With the new control model] you can't hide inconvenient things in 40 closely written pages anymore; you have to put them on the table". He also asserted that; "It's not a wild guess that many part-time politicians 
don't have the ability, or the interest, to read financial texts and numbers...”, and "...it will be more difficult to start a controversy with us [the politicians] when we have this control model". The politicians also hoped that the new reform will change accountability in the operative parts of the administrative agency. More frequent and exhaustive evaluations and analysis of actions were expected, and this in turn was anticipated to lead to a more accountable administrative agency.

The administrators also expected that the new reform will make them more accountable to the politicians. On of the administrators asserted that; "We will be forced to lay everything on the table for the politicians". The administrators also had hopes that the new reform will make operative employees more accountable for their actions. The administrators used expressions like; "coerce", "push down [accountability]", and "press out [accountability]" when they described how the operative employees were expected to be more accountable. One issue of special interest for the administrators' was the accountability concerning how the operative treat the clients. The chief financial officer for the administrative agency claimed that; "It's very important that you feel accountable farthest out in the organization... that we are here for the clients".

The operative employees had some expectations that they will be more accountable with the new reform, but they seemed to be unsure in what way. One of the practical nurses expressed her thoughts about more accountability; "I guess that there will be more pressure on us", and one of the supervisors felt that "something must happen, but I'm not sure of what". The operative employees were expecting that the new reform will make that the objectives will be tougher to achieve and they expected more evaluations of the reform. The operative employees also expected that the administrators will make them more accountable for how they treat the clients; something they believed that they always had been.

The expectations of more accountability from the administrative reform are highest among the politicians and the administrators. The expectations of the politicians of more accountable administrators indicate that they expect that the new reform will give them more power at the expense of the administrators. The reform is expected to make it harder for the administrators to withhold information to the politicians. The operative employees have expectations that the objectives will be hard to reach, but they expect only minor changes in terms of accountability with the new reform; they have always felt accountable for their action, especially for how they treat the clients.

\section{Legitimacy}

Today, organizations do not just compete for resources and customers; they also compete for political power and legitimacy (DiMaggio \& Powell, 1983). According to Suchman (1995, p. 574), organizational legitimacy refers to "a generalized perception or assumption that the actions of an entity [e.g. an organization] are desirable, proper, or appropriate within some socially constructed system of norms, values, beliefs, and definitions”.

It was only the administrators that had expectations that the new administrative reform will increase the legitimacy of the administrative agency. They hoped that it will come to the public attention that the administrative agency has a new control model and this in turn was expected to communicate that the administrative agency is; "A well-run and well managed organization”. The two administrators from the central administrative agency also hoped that the new reform will make the municipality a more attractive place to work in and an 
organization to look up to; "If we in the public sector can suddenly be a precursor in the society. That would give us more respect and then...WOW...we have something that makes us interesting to others".

The administrators' hope that it will come to the public attention that the administrative agency has a new control model indicates that they believe that it is difficult to legitimize the organizations. Some of the administrators appear to have the perception that others regard the public sector as a tedious and traditional place to work in, and that the new administrative reform is expected to change this picture. This indicates that it is the administrative reform per se and not the effects of applying the control model that has created this hope. A prerequisite for the realization of the administrators' hope is that the reform actually is communicated to the rest of the society, which is also a part of creating legitimacy from a new reform.

\section{Administration}

The aim of many NPM reforms is to improve efficiency and effectiveness. However, these reforms also tend to generate more administration (Barry et al, 2003) and this problem have been observed by Olson et al (2001) who denominates it as the public sectors' "evaluatory trap". This phenomenon occurs when public organizations invest in new accounting and control-based techniques in pursuit to become more efficient and effective, but end up with more targets, more measures, more monitoring and more evaluations that have increased the total cost per service unit by increasing the indirect costs. This is often solved by cutting the direct costs and/or by further investments in new techniques - which will increase the indirect costs further and the spiral continuous to spin. In the end, this problem will lead to fewer and fewer public services to higher and higher costs per unit.

A few of the administrators and one of the operative employees expressed expectations that the new administrative reform can lead to more administration. The process coordinator for the administrative agency perceived that there is a risk that the new reform can lead to more administration, but she also expressed worries that the operative employees will prioritize to work with the clients instead of revising objectives and measures since; "they [the operative employees] aren't used to working in this [new] way". However, the operative employees have to work with revisions when necessary. "They have no choice" according to a manager for one of the departments. One of the practical nurses expressed her thoughts regarding the administration of the new control model; "It could be good [the new control model], but it will also take time from us". She was worried that the new reform will consume time that she would rather use on the clients. The rest of the operative employees expressed no worries about more administration. They anticipated that most will be the same as it was before the new administrative reform was introduced.

More administration appears to be an expected disadvantage with the reform and necessary revisions of objectives and measures seems to be an activity that could be questioned and omitted by the operative employees. The practical nurse's worries that the administration of the control model (i.e. indirect costs) might consume time from the clients (direct costs), are in line with Olson et als' (2001) warning of the "evaluatory trap”. The reform could therefore lead to fewer services at higher cost per service unit. However, it is also important to revise objectives and measures. Otherwise, there is a risk that this administrative reform will be a product of drawing boards that slowly fade away. 
TABLE 1: Expectations from an administrative reform

\begin{tabular}{|c|c|c|c|}
\hline Theme & Politicians & Administrators & Operative employees \\
\hline Participation & $\begin{array}{l}\text { - Politicians will be more } \\
\text { participative in the design of } \\
\text { objectives for the political } \\
\text { council - this will give the } \\
\text { politicians more influence } \\
\text { and unite them }\end{array}$ & $\begin{array}{l}\text { - More participation in } \\
\text { the design of objectives } \\
\text { on every hierarchical } \\
\text { level - this will increase } \\
\text { motivation, commitment } \\
\text { and performances }\end{array}$ & $\begin{array}{l}\text { - More participation } \\
\text { in planning and } \\
\text { evaluations, but not in } \\
\text { decisions }\end{array}$ \\
\hline Effectiveness & $\begin{array}{l}\text { - By designing specific } \\
\text { objectives for the clients, } \\
\text { more focus will be on the } \\
\text { clients instead of financial } \\
\text { issues in the operative parts } \\
\text { of the organization }\end{array}$ & $\begin{array}{l}\text { - By designing and } \\
\text { evaluating objectives } \\
\text { related to the clients, the } \\
\text { operative employees will } \\
\text { treat the clients better }\end{array}$ & $\begin{array}{l}\text { - No changes of } \\
\text { priorities - the clients } \\
\text { will be prioritized and } \\
\text { treated well }\end{array}$ \\
\hline Accountability & $\begin{array}{l}\text { - The administrators and } \\
\text { the operative employees will } \\
\text { be more accountable to the } \\
\text { politicians }\end{array}$ & $\begin{array}{l}\text { - The administrators } \\
\text { will be more accountable } \\
\text { to the politicians and the } \\
\text { operative employees will } \\
\text { be more accountable for } \\
\text { how they treat the clients }\end{array}$ & $\begin{array}{l}\text { - The operative } \\
\text { employees will be } \\
\text { somehow more } \\
\text { accountable for how } \\
\text { they treat the clients }\end{array}$ \\
\hline Legitimacy & $\begin{array}{l}\text { - No expectations } \\
\text { expressed }\end{array}$ & $\begin{array}{l}\text { - The organization will } \\
\text { be conceived as } \\
\text { professional managed } \\
\text { and interesting }\end{array}$ & $\begin{array}{l}\text { - No expectations } \\
\text { expressed }\end{array}$ \\
\hline Administration & $\begin{array}{l}\text { - No expectations } \\
\text { expressed }\end{array}$ & $\begin{array}{l}\text { - Some risk of more } \\
\text { administration }\end{array}$ & $\begin{array}{l}\text { - A risk that time will } \\
\text { be taken from the } \\
\text { clients }\end{array}$ \\
\hline
\end{tabular}

\section{Conclusions and discussion}

This case study explores what politicians, administrators and operative employees' expect from a new administrative reform that is carried out in a public sector organization. The reform concerns an attempt to implement the Balanced Scorecard in a political council and an administrative agency in a Swedish municipality. Through the analysis and interpretation of empirical data, five distinctive themes of expectations from the reform are identified; participation, effectiveness, accountability, legitimacy and administration.

The findings shows that the expectations of significant changes from the administrative reform are highest among the politicians, moderate among the administrators and lowest among the operative employees. The politicians expect that the new administrative reform will lead to more accountability, higher effectiveness and more participation in the organization. An explanation to the relatively high expectations of the politicians is that most of the anticipated changes will favour them. More participation in the design of objectives for the political council together with more accountable administrators will give the politicians 
more influence and power over the administrative agency, compared with earlier management control that foremost favoured the administrators. Further, improved organizational effectiveness in terms of more focus on the clients is important for the politicians in order to win sympathies from the voters. The administrators also expect that the new administrative reform will lead to higher effectiveness, more accountability and more participation in the organization, but their expectations is not as high as the expectations of the politicians. An explanation to the difference can be that the administrators expect that some aspects of the reform will favour them, while other aspects will not. The administrators have high hopes that the new administrative reform will increase the legitimacy of the organization, which seem to be important for them and an expected advantageous. The administrators also anticipate that they will lose some influence and power over the administrative agency by the new reform and this is probably an expected disadvantage with the reform. The operative employees expect that the new administrative reform will lead to only minor changes in the organization, but most is expected to remain unchanged. An explanation to their low expectations can be that the operative employees have lost their faith of reforms due to the administrative agency's history of earlier reform failures. The operative employees are also suspicious that this particular reform is a disguised way to cut down the work force. If this is true, the reform would certainly disfavour the operative employees. Interesting enough, considering the large budget deficit of the administrative agency, improved efficiency was not what politicians, administrators or operative employees expected from the new administrative reform. Another finding is that some of the expectations expressed concern expectations of the new administrative reform (i.e. expectations of changes, or not changes, from applying the Balanced Scorecard), while other expressions are expectations on the new administrative reform (i.e. expectation on the reform per se, rather than changes, or not changes, from applying the Balanced Scorecard). Expectations of the reform concern all expectations from the politicians, the operative employees and most of the expectation from the administrators, while expectations on the reform concern the administrators' hope of increased legitimacy for the organization by carry out the new administrative reform.

Based on the abovementioned, one conclusions of the study is that the politicians, the administrators and the operative employees that participate in the study have different expectations from the administrative reform. The differences in expectations can be explained by anticipations of how the reform will favour or disfavour the actors, which in turn seems to be influenced by their past experiences of management control and administrative reforms. Another conclusion is that most of the expectations expressed concern expectation of the new administrative reform, but some expectations also concern expectations on the new administrative reform.

This exploratory study of expectations from administrative reforms reveals more than just expectations. One observation is that it seems clear that the politicians and the administrators do not share the same reality as the operative employees. The former seems to believe that the operative employees prefer to prioritize financial issues rather than making the clients satisfied, which based on the findings in this study, must be a misconception. The expectations of the operative employees clearly indicate that they would like to prioritize the clients more, but they feel restricted by the decisions and actions of the politicians and the administrators. This indicates that the organization in reality has high goal congruence, but not in the perceptions of the actors from the political council and the administrative agency. Considering the large budget deficit, this state can lead to further financial problems for the administrative agency, especially if the new reform is used as expected by the politicians and the administrators; to promote more focus on the clients and less focus on financial issues to 
the operative employees. Therefore, there is a risk that the new administrative reform can create a reversed goal congruence problem by generating a large unbalance between financial efforts and client-related efforts in the operative parts of the administrative agency. There is also a paradox hiding behind the expectation of the administrators related to the clients. They express hopes that the new reform will make it clear to the operative employees that they should prioritize the clients, but they also express worries that the operative employees will prioritize the clients before making necessary revisions of objectives and measures. Does this mean that the reform in reality is more important than the clients for the administrators, or is it just an indication of organizational hypocrisy where talk, decisions and actions are separated from each other (c.f. Brunsson, 1989b)?

A study of expectations can also be used to predict future events. Based on the findings in this study and earlier research on information systems (i.e Ginzberg, 1981; Szanja \& Scamell, 1993), this particular reform has a risk to fail for at least two reasons. First, since the operative employees have low expectations of changes from the reform and low expectations of the usefulness of the control model, there is a risk that they will not apply the model in such extent that future performance effects become possible from the model. Secondly, there is a risk that the somehow unrealistic high expectations of the politicians on the control model can lead to an expectation failure (Lyytinen, 1988) which occurs when there is a gap between expectations expressed in ideals and the actual performance of a system. Only the future can tell if this prophecy will be realized.

Finally, this study has shown that the expectations from an administrative reform in a public organization are different for politicians, administrators and operative employees. The reform seems to have created images of the future in the minds of the actors and these images appear to be more or less influenced by their past experiences and future anticipations. The actors seem to selectively mix parts of the history with parts of the reform while they create their expectations. This implies that there can be a duality between expectations and administrative reforms, which in such case, mean that we should not see administrative reforms just as phenomenon that creates expectations, but also as phenomenon that is created by expectations. However, this duality must be explored more before such conclusions can be drawn. Future research can also be directed to further exploring if some of findings in this study are valid in other context or for other administrative reforms. For example, are the differences in expectations between politicians, administrators and operative employees found in this study similar in other public organization settings or for other administrative reforms? Future research can also explore how pre-implementation expectations from administrative reforms in public sector organizations affect post-implementations perceptions and success or failures of reforms. 


\section{References}

Abrahamson, E. (1991). Managerial Fads and Fashions: The Diffusion and Rejection of Innovation. Academy of Management Review, Vol. 19, No 3, pp. 586-612.

Abrahamson, E. (1996). Management Fashion. Academy of Management Review, Vol. 21, No 1, pp. 254-285.

Alutto, J. A., \& Belasco, J. A. (1972). A Typology for Participation in Organizational Decision Making. Administrative Science Quarterly, Vol. 17, No. 1, pp. 117-125.

Ax, C., Bjørnenak, T., (2007). Management accounting innovations: origins and diffusion. In: Hopper, T., Northcott, D., Scapens, R.W, (Eds.). Issues in Management Accounting (3rd edition), Hertfordshire: Prentice-Hall, pp. 357-376.

Bainbridge, S.M. (1996). Participatory Management Within a Theory of the Firm. The Journal of Corporation Law, Vol. 21, No. 4.

Barry, J., Berg, E., \& Chandler, J. (2003). Managing Intellectual Labour in Sweden and England. Cross Cultural Management, Vol. 10, No. 3, pp. 3-22.

Bovens, M. (2005). Public Accountability. Chapter 8 in Ferlie, E., Lynne L., \& Pollitt C. (Eds.). The Oxford Handbook of Public Management. Oxford: Oxford University Press.

Brunsson, N. (1989a). Administrative reforms as routines. Scandinavian Journal of Management, Vol. 5, No. 3, pp. 219-228.

Brunsson, N. (1989b). The Organization of Hypocrisy. Talk, Decisions and Actions in Organizations. Malmö: Liber Ekonomi.

Brunsson, N., \& Olsen, J.P. (1993). The Reforming Organization. London: Routledge.

Brunsson, N. (2006a). Reforms, organization, and hope. Scandinavian Journal of Management, Vol. 22, pp. 253-255.

Brunsson, N. (2006b). Mechanism of hope. Maintaining the Dream of the Rational Organization. Malmö: Liber AB.

Cameron, K. (1981). Construct Space and Subjectivity Problems in Organizational Effectiveness. Public Productivity Review, Vol. 5, No. 2, pp. 105-121.

Christensen, T., \& Lægreid, P. (1999). New Public Management: Design, Resistance, or Transformation? A Study of How Modern Reforms Are received in a Civil Service System. Public Productivity \& Management Review, Vol. 23, No. 2, pp. 169-193.

Coulter, P.B. (1979). Organizational Effectiveness in the Public Sector: The Example of Municipal Fire Protection. Administrative Science Quarterly, Vol. 24, No. 1, pp. 65-81.

Denzin, N.K., \& Lincoln, Y.S. (2000). Handbook of qualitative research. Thousand Oaks: Sage Publications, Inc.

DiMaggio, P.J., \& Powell, W.W. (1983). The Iron Cage Revisited: Institutional Isomorphism and Collective Rationality in Organizational Fields. American Sociological Review, Vol. 48, No. 2, pp. 147-160.

Dinesh, D., \& Palmer, E. (1998). Management by objectives and the Balanced Scorecard: will Rome Fall Again? Management Decisions, 36/6, pp. 363-369.

Doolin, B. (2004). Power and resistance in the implementation of a medical management information system. Information Systems Journal, 14, pp. 343-362.

Fitzgerald, L., Johnston, R., Brignall, S., Silvestro, R., \& Voss, C. (1991). Performance Measurement in Service Businesses. London: CIMA.

Forsell, A. (2002). Reform Theory Meets New Public Management. In: Christensen, T., \& Lægreid, P. (Eds.). New Public Management. The transformation of ideas and practice. Hampshire: Ashgate Publishing Limited, pp. 261-287.

Ginzberg, M.J. (1981, April). Early Diagnosis of MIS Implementation Failure: Promising Results and Unanswered Questions. Management Science, Vol. 27, No. 4, pp. 459-478. 
Grusky, O. (1963). Managerial Succession and Organizational Effectiveness. The American Journal of Sociology, Vol. 69, No, pp. 21-31.

Hood, C. (1995). The "New Public Management” in the 1980:s Variations on a Theme. Accounting, Organizations and Society, Vol. 20, No. 2/3, pp. 93-109.

Hubbert, A.R., Sehorn, A.G., \& Brown, S.W. (1995). Service expectations: the consumer versus the provider. International Journal of Service Industry Management, Vol. 6, No. 1, pp. 6-21.

Ives, B., \& Olson, M.H. (1984). User Involvement and MIS Success: A Review of Research. Management Science, Vol. 30, No. 5, pp. 586-603.

Kanji, G.K., \& Moura e Sá, P. (2001). Kanji’s Business Scorecard. Total Quality Management, Vol. 12, No. 7\&8, pp. 898-905.

Kaplan, R.S., \& Norton, D.P. (1992). The Balanced Scorecard - Measures That Drive Performance. Harvard Business Review, pp. 71-79.

Kaplan, R.S., \& Norton, D.P. (1996). The Balanced Scorecard: Translating Strategy into Actions. Boston: Harvard Business School Press.

Kasurinen, T. (2002). Exploring management accounting change: the case of balanced scorecard implementation. Management Accounting Research, 13, pp. 323-343.

Lapsley, I., \& Wright, E. (2004). The diffusion of management accounting innovations in the public sector: a research agenda. Management Accounting Research, Vol. 15, Issue 3, pp. 355-374.

Locke, E.A., \& Schweiger, D. M. (1979). Participation in Decision Making: One More Look. Research in Organizational Behaviour, Vol. 1, pp. 265-339.

Lynch, R. \& Cross, K.F. (1991). Measure Up! Yardsticks for Continuous Improvements. Basil Blackwell.

Lyytinen, K. (1988). Expectation Failure Concept and Systems Analysts’ View of Information System Failures: Results of an Exploratory Study. Information \& Management, 14, pp. 45-54.

Macintosh, N. B. (1985). The Social Software of Accounting and Information Systems. Chichester: John Wiley \& Sons.

Macintosh, N.B. (1994). Management Accounting and Control Systems. An Organizational and Behavioral Approach. Chichester: John Wiley \& Sons.

Malmi, T. (2001). Balanced scorecard in Finnish companies: A research note. Management Accounting Research, 12, pp. 207-220.

Meyer, J.W., \& Rowan, B. (1977). Institutionalized Organizations: Formal Structure as Myth and Ceremony. American Journal of Sociology, Vol. 83, No. 2, pp. 340-363.

Modell, S. (2004). Performance Measurement Myths in the Public Sector: A Research Note. Financial Accountability \& Management, 20(1), pp. 39-54.

Nilsson, K. (2005). Förväntningar på en flerdimensionell styrmodell. Införandet av balanserad styrning inom en kommunal nämnd/förvaltning. Licentiate thesis. Institutionen för industriell ekonomi och samhällsvetenskap. Luleå University of Technology.

Olson, O., Humphrey, C., \& Guthrie, J. (2001). Caught in an evaluatory trap: a dilemma for public services under NPFM. The European Accounting Review, 10:3, pp. 505-522.

Olve, N-G., Roy, J., \& Wetter, M. (1999). Balanced Scorecard i svensk praktik. Malmö: Liber Ekonomi.

Quinn, R.E., \& Rohrbaugh, J. (1981). A Competing Values Approach to Organizational Effectiveness. Public Productivity Review, Vol. 5, No. 2, pp. 122-140.

Roberts, J. (1991). The Possibilities of Accountability. Accounting, Organizations and Society, Vol. 16, No. 4, pp. 355-368. 
Roberts, J. \& Scapens, R. (1985). Accounting Systems and Systems of Accountability Understanding Accounting Practices in their Organisational Contexts. Accounting, Organizations and Society, Vol. 10, No. 4, pp. 443-456.

Sahlin-Andersson, K. (2002). National, International and Transnational Constructions of New Public Management. In: Christensen, T., \& Lægreid, P. (Eds.). New Public Management. The transformation of ideas and practice. Hampshire: Ashgate Publishing Limited, pp. 43-72.

Salskov-Iversen, D., Hansen, H.K. \& Bislev, S. (2000). Governmentality, globalization, and local practice: Transformations of a hegemonic discourse. Alternatives: Social Transformation \& Humane, Vol. 25, Issue 2, pp. 183-223.

Sinclair, A. (1995). The Chameleon of Accountability: Forms and Discourses. Accounting, Organizations and Society, Vol. 20, No. 2/3, pp. 219-237.

Staples, D.S., Wong, I., \& Seddon, P.B. (2002). Having expectations of information systems benefits that match received benefits: does it really matter? Information \& Management (40), pp. 115-131.

Stone, D.N. (1995). The Joint Effects of DSS Feedback and Users' Expectations on Decision Processes and Performance. Journal of Information Systems, Spring95, Vol. 9, Issue 1, pp. 23-41.

Storey, A. (2002). Performance Management in Schools: could the Balanced Scorecard help? School Leadership \& Management, Vol. 22, No. 3, pp. 321-338.

Suchman, M.C. (1995). Managing Legitimacy: Strategic and Institutional Approaches. The Academy of Management Review, Vol. 20, No. 3, pp. 571-610.

Sunder, S. (2002). Management Control, Expectations, Common Knowledge, and Culture. Journal of Management Accounting Research, Vol. 14, pp. 173-187.

Szajna, B., \& Scamell, R. (1993). The Effects of Information System User Expectations on Their Performance and Perceptions. MIS Quarterly, pp. 493-516.

Yin, R.K. (1994). Case study research. Design and Methods. Thousand Oaks: Sage Publications, Inc. 